Volume 2 Nomor 2, November 2021: h. 109 - 125

P-ISSN: 2722-4465, E-ISSN: 2746-8151

Lisensi Creative Commons Atribusi-NonCommercial 4.0 Internasional

\title{
Efektifitas Kebijakan Program Adiwiyata Dalam Mencetak Generasi Penerus Bangsa Peduli Lingkungan Di Indonesia
}

\section{Dinarjati Eka Puspitasari}

Fakultas Hukum Universitas Gadjah Mada, Yogyakarta, Indonesia

E-mail: dinarjati@ugm.ac.id

\begin{tabular}{l}
\multicolumn{1}{c}{ Dikirim: $30 / 10 / 2021$} \\
\hline Info Artikel \\
\hline Keywords: \\
Effectiveness of Adiwiyata \\
Policy; The Next Generation; \\
Environmental Care. \\
\\
Lingkungan. \\
Pata Kunci: \\
Pdiwiyata; Generasi \\
Eenerus Bangsa; Peduli \\
\hline
\end{tabular}

Direvisi: 15/11/2021

Dipublikasi: 27/11/2021

\section{Abstract}

Adiwiyata Program is a program implemented by the State Ministry of Environment and Forestry to create schools that care and have an environmental culture. This program aims to save and preserve the environment for the benefit of future generations, followed by schools from elementary to secondary levels. Adiwiyata program is expected to produce students who are young generations to care for the environment. This research aims to examine the need to promote adiwiyata program policies in creating the next generation who cares about the environment throughout Indonesia; the effectiveness of Adiwiyata program policies in creating the nation's next generation; the need for a role from the Government related to Adiwiyata program policies in creating the next generation of the nation who cares about the environment in Indonesia. This research is a normative legal research. The research materials are taken from literature study. Qualitative descriptive approach is employed to analyse the materials. This research generates some results: 1) Adiwiyata program policies in creating the nation's next generation who care about the environment need to be encouraged in schools throughout Indonesia, because it is positive for the development of the nation's next generation in an effort to preserve environmental functions, to create a good and healthy living environment; 2) Adiwiyata program policy has been running effectively, although it has not been optimal in creating the nation's next generation; 3) The role of the Government is needed in relation to the Adiwiyata program policy in creating the next generation who cares about the environment in Indonesia, to provide environmental awareness for citizens.

\begin{tabular}{l}
\hline Abstrak \\
Program Adiwiyata merupakan program yang dilaksanakan oleh \\
Kementrian Negara Lingkungan Hidup Dan Kehutanan untuk \\
mewujudkan sekolah yang peduli dan berbudaya lingkungan \\
hidup. Program ini bertujuan untuk menyelamatkan dan \\
melestarikan lingkungan hidup untuk kepentingan generasi yang \\
akan datang, diikuti oleh sekolah-sekolah dari tingkat dasar \\
sampai dengan menengah. Program Adiwiyata diharapkan dapat \\
mencetak para murid yang merupakan generasi muda agar peduli \\
terhadap lingkungan hidup. Penelitian ini bertujuan untuk \\
mengkaji perlunya digalakkan kebijakan program adiwiyata \\
dalam mencetak generasi penerus bangsa yang peduli lingkungan
\end{tabular}


DOI:

10.47268/ballrev.v2i2.654 di seluruh Indonesia; keefektifan kebijakan program adiwiyata dalam mencetak generasi penerus bangsa; perlunya peran dari Pemerintah terkait kebijakan program adiwiyata dalam mencetak generasi penerus bangsa yang peduli lingkungan di Indonesia. Penelitian ini merupakan penelitian hukum normatif. Bahan penelitian menggunakan penelitian pustaka. Metode analisis data dengan menggunakan deskriptif kualitatif. Hasil penelitian ini membahas mengenai 1) kebijakan program adiwiyata dalam mencetak generasi penerus bangsa yang peduli lingkungan perlu digalakkan di sekolah seluruh Indonesia, karena bernilai positif bagi perkembangan generasi penerus bangsa dalam upaya melestarikan fungsi lingkungan hidup, Untuk mewujudkan lingkungan hidup yang baik dan sehat; 2) kebijakan program adiwiyata telah berjalan efektif, meski belum optimal dalam mencetak generasi penerus bangsa; 3) peran Pemerintah diperlukan terkait kebijakan program adiwiyata dalam mencetak generasi penerus bangsa yang peduli lingkungan di Indonesia, untuk memberikan kesadaran lingkungan bagi warga.

\section{Pendahuluan}

Program Adiwiyata merupakan program yang telah dilaksanakan oleh Kementrian Negara Lingkungan Hidup Dan Kehutanan untuk mewujudkan sekolah yang peduli dan berbudaya lingkungan hidup. Program ini bertujuan untuk menyelamatkan dan melestarikan lingkungan hidup untuk kepentingan generasi yang akan datang. Program Adiwiyata ini diikuti oleh sekolah-sekolah dari tingkat dasar sampai dengan menengah. Sekolah-sekolah tersebut meliputi Sekolah Dasar (SD) dan/atau sederajad; Sekolah Menengah Pertama (SMP) dan/atau sederajad; Sekolah Menengah Atas (SMA) dan/atau sederajad. Berdasar data dari Kementrian Lingkungan Hidup dan Kehutanan, pada bulan Desember 2019, sebanyak 434 sekolah yang terdiri atas 376 sekolah negeri dan 58 sekolah swasta dari 164 kota/kabupaten di 32 propinsi, berhasil mendapatkan penghargaan Adiwiyata Nasional (333 sekolah) dan Adiwiyata Mandiri (101 sekolah) (Hadi, 2019). Penghargaan Adiwiyata diberikan oleh Menteri, Gubernur, dan Bupati/Wali Kota kepada sekolah yang berhasil melaksanakan Gerakan Peduli Dan Berbudaya Lingkungan Hidup Di Sekolah (Gerakan PBLHS) sebagaimana dalam Pasal 2 Peraturan Menteri Lingkungan Hidup Dan Kehutanan Nomor P.53/MENLHK/SETJEN/KUM.1/9/2019 tentang Penghargaan Adiwiyata. Adapun jenis penghargaan adiwiyata tersebut yang mampu diterima oleh sekolah meliputi: penghargaan adiwiyata nasional, penghargaan adiwiyata propinsi, penghargaan adiwiyata kabupaten/kota; serta penghargaan adiwiyata mandiri (Ibeng, 2019). Penyerahan Penghargaan Adiwiyata Nasional dan Adiwiyata Mandiri tersebut telah dilaksanakan sebanyak 13 kali, sejak dilaksanakan pada tahun 2006. Pemberian penghargaan Adiwiyata Nasional pertama kali dilaksanakan tahun 2007 yang diperuntukkan bagi lingkup sekolah-sekolah di Pulau Jawa (Hadi, 2019). Tercatat hingga Desember 2019, dari sekitar 250.000 sekolah di seluruh Indonesia, 
4.305 sekolah diantaranya telah meraih penghargaan Adiwiyata Nasional, terdiri dari 3.477 sekolah dan Adiwiyata Mandiri 828 sekolah (Hadi, 2019).

Program adiwiyata ini penting diterapkan di berbagai sekolah, karena banyak kegiatan positif terkait dengan pelestarian lingkungan yang digalakkan di sini. Program ini perlu didukung oleh guru, tenaga kependidikan, para peserta didik/murid, serta masyarakat sekitar sekolah tersebut berada. Program adiwiyata ini juga perlu mendapatkan bantuan dan kerjasama dari dinas terkait maupun organisasi pecinta lingkungan yang mempunyai kepedulian terhadap program tersebut. Diharapkan kegiatan pelestarian lingkungan yang dilakukan oleh sekolah tersebut, akan mempunyai dampak positif terhadap para peserta didik atau murid tersebut. Tidak hanya terbatas saat para murid tersebut bersekolah atau saat mengenyam pendidikan saja di sekolah tersebut, tetapi juga saat mereka telah lulus sekolah. Program Adiwiyata telah berhasil mendorong adanya peningkatkan upaya perlindungan dan pengelolaan lingkungan hidup di sekolah. Selama kurun waktu tahun 2006 - 2019, sekolah adiwiyata telah memberikan kontribusi berupa pengurangan timbunan sampah melalui pengelolaan sampah dengan metode $3 \mathrm{R}$ (reuse, reduce dan recycle) sejumlah 38.745 ton per tahun. Sekolah-sekolah tersebut juga berkontribusi dalam penanaman dan pemeliharaan 322.875 pohon/tanaman, serta 64.575 lubang biopori, serta 12.915 sumur resapan. Di samping itu, sekolahsekolah tersebut mampu menghemat penggunaan listrik dan air antara $10-40 \%$ per sekolah (Hadi, 2019).

Dalam hal ini, karena muatan kegiatan-kegiatan dari sekolah berbudaya lingkungan terhadap usaha pelestarian lingkungan tersebut sangat positif, maka diharapkan program adiwiyata ini dapat dilakukan di sekolah-sekolah di seluruh Indonesia. Oleh karena pentingnya pelestarian lingkungan yang dilakukan di sekolah-sekolah berbudaya lingkungan, perlu adanya perlindungan dan pengawasan dari pemerintah. Dalam hal ini perlu ada reward jika program adiwiyata ini berhasil mencetak generasi penerus bangsa yang peduli terhadap lingkungan. Di samping itu juga perlu dilakukan koordinasi antar dinas-dinas yang terkait dengan pelaksanaan program adiwiyata tersebut.

Program adiwiyata tersebut telah diatur dalam Peraturan Menteri Negara Lingkungan Hidup Nomor 5 Tahun 2013 tentang Pedoman Pelaksanaan Adiwiyata Pasal 3. Peraturan ini bertujuan untuk memberikan arah dan pedoman pelaksanaan program adiwiyata kepada seluruh unsur pelaksana program adiwiyata baik di tingkat pusat maupun daerah. Peraturan ini kemudian digantikan Peraturan Menteri Lingkungan Hidup Dan Kehutanan Nomor P.53/MENLHK/SETJEN/KUM.1/9/2019 tentang Penghargaan Adiwiyata. Di samping itu, juga terdapat Peraturan Menteri Lingkungan Hidup Dan Kehutanan Nomor P.52/MENLHK/ SETJEN/KUM.1/9/2019 tentang Gerakan Peduli Dan Berbudaya Lingkungan Hidup Di Sekolah. Gerakan PBLHS ini bertujuan untuk mewujudkan perilaku warga sekolah yang bertanggung jawab dalam upaya pelestarian fungsi lingkungan hidup serta peningkatan kualitas lingkungan hidup sebagaimana dalam Pasal 2 ayat (1) Peraturan Menteri Lingkungan Hidup Dan Kehutanan Nomor P.52/MENLHK/ SETJEN/KUM.1/9/2019 Gerakan Peduli Dan 
Berbudaya Lingkungan Di Sekolah. Dalam ketiga peraturan tersebut perlu untuk ditinjau lebih lanjut mengenai efektifitas peraturan tersebut dalam mencetak generasi muda yang peduli terhadap lingkungan hidup. Terkait hal tersebut, manusia merupakan bagian dari lingkungan hidup; manusia mempunyai hubungan timbal balik dengan lingkungannya, aktifitasnya mempengaruhi dan dipengaruhi oleh lingkungan hidup (Silalahi \& Kristianto, 2015: 10). Di samping itu, juga perlu ditinjau bagaimana peran Pemerintah dalam melakukan pengawasan efektifitas pengaturan pelaksanaan program adiwiyata tersebut.

Alasan di atas perlu ditekankan karena program adiwiyata tersebut diharapkan dapat mencetak para murid yang merupakan generasi muda agar peduli terhadap lingkungan, baik di mana mereka bersosialisasi terhadap masyarakat sekitar maupun saat mereka bertempat tinggal/berdomisili di suatu wilayah tertentu. Kepedulian lingkungan diharapkan tidak hanya bersifat sementara saat mereka bersekolah saja, tetapi akan menjadi karakter bagi para generasi muda yang akan menjadi penerus bangsa. Peduli lingkungan dilakukan untuk melakukan pelestarian dan penyelamatan terhadap lingkungan hidup serta merawat bumi yang telah semakin tua. Di samping itu juga dilakukan untuk mengurangi dampak negative dari terjadinya pencemaran dan/atau kerusakan lingkungan hidup serta terkurasnya sumber daya alam (Rahmadi, 2019: 1-3). Terkait hal tersebut, penelitian ini menjelaskan mengenai sampai seberapa jauh efektifitas kebijakan program adiwiyata tersebut dalam mencetak generasi penerus bangsa yang peduli terhadap lingkungan hidup.

\section{Metode Penelitian}

Penelitian ini merupakan penelitian hukum hukum normatif, yaitu melakukan identifikasi jenis peraturan, aplikasi dan relevansi aturan hukum regional dan nasional yang mengatur masalah program adiwiyata serta gerakan peduli dan berbudaya lingkungan hidup. Untuk melengkapi atau menambah bahan hukum sekunder dalam penelitian normatif ini, peneliti akan melakukan wawancara dengan beberapa narasumber. Bahan penelitian didapat dengan penelitian kepustakaan. Untuk itu penelitian akan dilakukan dengan studi pustaka yang mengkaji bahan hukum. Data yang didapat dari penelitian kepustakaan adalah data sekunder. Data sekunder meliputi bahan hukum primer, sekunder, tersier. Teknik pengumpulan data dalam penelitian ini dilakukan dengan studi pustaka dan alat penelitian berupa wawancara yang ditujukan pada narasumber. Metode penelitian data menggunakan deskriptif kualitatif.

\section{Hasil dan Pembahasan}

\subsection{Program Adiwiyata Untuk Mewujudkan Lingkungan Hidup Yang Baik Dan Sehat}

Hak atas lingkungan hidup yang baik dan sehat telah diatur di dalam Pasal $28 \mathrm{H}$ ayat (1) UUD 1945, yang menyatakan bahwa "setiap orang berhak hidup sejahtera lahir dan batin, bertempat tinggal dan mendapatkan lingkungan hidup yang baik dan sehat serta berhak memperoleh pelayanan kesehatan." Terkait pasal tersebut 
dapat dijelaskan bahwa Indonesia telah menyadari pentingnya jaminan pemenuhan hak atas lingkungan hidup bagi seluruh rakyat Indonesia. Hak atas lingkungan tersebut merupakan suatu hak yang melekat pada setiap individu warga negara Indonesia dan menyangkut eksistensi dari hak hidup manusia (Tim Kajian Kerjasama ICEL dan IICT, 2005: 10).

Dalam Pasal 65 ayat (1) UUPPLH menjelaskan mengenai lingkungan hidup yang baik dan sehat merupakan bagian dari hak asasi manusia. Hak tersebut mengandung tuntutan yang bersifat hak asasi sosial, karena sekaligus diimbangi dengan kewajiban bagi pemerintah untuk menggariskan kebijaksanaan dan melakukan tindakan yang mendorong ditingkatkannya upaya pelestarian kemampuan lingkungan hidup (Fadli et al., 2016: 75). Konsep Hak Asasi Manusia di Indonesia bukan saja termasuk hak-hak mendasar manusia, tetapi juga merupakan kewajiban dasar manusia sebagai warga negara untuk mematuhi peraturan perundangan, hukum tidak tertulis, menghormati HAM orang lain, moral serta etika (Muladi, 2009).

Hak atas lingkungan hidup yang baik dan sehat harus dipelihara, dikembangkan, dilindungi, dilestarikan, fungsinya agar bermanfaat bagi kehidupan manusia dan makhluk hidup lainnya (Sod, 2019: 8). Hak atas lingkungan hidup yang baik dan sehat tersebut terkait dengan kegiatan pelestarian fungsi lingkungan. Hal tersebut berkaitan dengan kegiatan pendidikan lingkungan hidup yang diselenggarakan di sekolah-sekolah dasar maupun menengah. Kegiatan tersebut dapat berupa pengadaan dan/atau penanaman pohon perindang serta penanaman tanaman hidroponik dan tanaman toga yang hasilnya dapat dilakukan untuk kegiatan wirausaha di sekolah tersebut. Di samping itu juga terdapat kegiatan pemilahan dan daur ulang sampah yang dilakukan pada beberapa sekolah pengikut program adiwiyata.

KLHK telah memberikan arahan terkait dengan program-program yang dilakukan untuk kegiatan pendidikan lingkungan hidup yang dilaksanakan untuk sekolah-sekolah di Indonesia. Berdasarkan wawancara tertulis dengan Ibu Asri Tresnawati, Kepala Bidang Pengembangan Generasi Lingkungan, Kementrian Kehutanan dan Lingkungan Hidup (KLHK), mengatakan bahwa terdapat berbagai aspek yang perlu dilakukan sekolah-sekolah di Indonesia untuk melakukan kegiatan pendidikan lingkungan hidup. Kegiatan tersebut meliputi berbagai aspek tentang program-program pendorong Pola Hidup Bersih Dan Sehat (PHBS). Program tersebut meliputi berbagai aspek pelestarian fungsi lingkungan hidup, meliputi: aspek kebersihan, sanitasi, drainase; aspek pengelolaan sampah; aspek penanaman dan pemeliharaan pohon atau tanaman; aspek konservasi air; aspek konservasi energi; aspek inovasi terkait penerapan Perilaku Ramah Lingkungan Hidup (PRLH). Berbagai aspek yang terkait dengan program KLHK tersebut telah dikemas dan diintegrasikan dalam berbagai kegiatan mata pelajaran, kegiatan ekstra kurikuler serta pembiasan diri mengenai PHBS di sekolah. Kegiatan-kegiatan di atas telah dilanjutkan oleh pihak sekolah untuk dimasukkan dalam kurikulum pendidikan di sekolah tersebut. Dalam hal ini, para pengajar, peserta didik (murid) dan warga 
sekitar sekolah memiliki kewajiban yang sama dalam melestarikan fungsi lingkungan hidup untuk mewujudkan lingkungan sekolah yang baik dan sehat.

Terkait hal tersebut di atas, diharapkan kegiatan pendidikan lingkungan hidup yang diterapkan di sekolah tersebut, dapat mewujudkan lingkungan hidup yang baik dan sehat. Dengan budaya kebersihan lingkungan, kegiatan penanaman pohon, serta penerapan perilaku ramah lingkungan hidup tersebut diharapkan dapat meningkatkan kesehatan jasmani dan rohani para peserta didik beserta tenaga pengajar.

\subsection{Kebijakan Program Adiwiyata Dalam Mencetak Generus Penerus Bangsa Peduli Lingkungan Perlu Digalakkan Di Seluruh Indonesia}

Kegiatan utama program adiwiyata bertujuan untuk terwujudnya kelembagaan sekolah yang peduli dan berbudaya lingkungan berdasar partisipatif dan berkelanjutan. Adapun institusi yang menjadi sasaran sekolah adiwiyata meliputi Sekolah Dasar dan sederajat, Sekolah Menengah Pertama dan sederajat, Sekolah Menengah Atas dan sederajat (Haris et al., 2018: 8).

Kata adiwiyata berasal dari bahasa sansekerta, yang memiliki makna: adi berarti besar, baik, agung, ideal, dan sempurna. Selain itu wiyata berarti tempat yang baik dan ideal untuk memperoleh segala ilmu pengetahuan, norma, dan etika dalam kehidupan social. Oleh karena itu, adiwiyata dapat diartikan sebagai tempat yang baik dan ideal untuk memperoleh ilmu pengetahuan, norma, dan etika yang menjadi dasar manusia menuju terciptanya kesejahteraan hidup menuju cita-cita.

Program adiwiyata bertujuan untuk menciptakan kondisi yang baik bagi sekolah untuk menjadi tempat pembelajaran dan tempat penyadaran pendidik, tenaga kependidikan, peserta didik serta warga sekitar sekolah. Program tersebut dilakukan sebagai upaya mendorong penyelamatan lingkungan dan pembangunan berkelanjutan agar dapat mewujudkan sekolah yang peduli dan berbudaya lingkungan (Widyaningrum, 2019), dalam hal ini pembangunan berkelanjutan di sini dapat diartikan sebagai wujud pelestarian fungsi lingkungan hidup yang dilakukan di sekolah-sekolah pengikut program adiwiyata. Terkait hal tersebut diharapkan program adiwiyata ini dapat mewujudkan lingkungan hidup yang baik dan sehat. Lingkungan yang baik akan memacu dan menambah semangat serta optimis kegiatan belajar mengajar, dimana para murid, pengajar dan warga sekitar sekolah melakukan kegiatan pelestarian fungsi lingkungan hidup, sehingga tercipta suasana lingkungan yang asri, nyaman, segar, teduh, dan tidak gerah. Dengan keadaan tersebut, dapat diwujudkan lingkungan yang sehat baik jasmani maupun rohani dalam mendukung pelaksanaan kegiatan belajar mengajar. Lingkungan sekolah dapat menjadi yang lingkungan yang bersih, dengan kegiatan pemilahan dan daur ulang sampah. Kegiatan tersebut sebagai sarana mewujudkan lingkungan sekolah yang sehat, terhindar dari berbagai penyakit akibat lingkungan yang tidak bersih.

Terkait hal tersebut di atas, karena program adiwiyata bernilai positif bagi perkembangan generasi penerus bangsa dalam upaya melestarikan fungsi lingkungan hidup, maka kebijakan yang mengaturnya perlu digalakkan di sekolah- 
sekolah dari tingkat dasar sampai menengah di seluruh Indonesia. Kebijakan yang telah dikeluarkan Kementrian Lingkungan Hidup Dan Kehutanan yaitu Peraturan Menteri Lingkungan Hidup Republik Indonesia Nomor 5 Tahun 2013 tentang Pedoman Pelaksanaan Program Adiwiyata; Peraturan Menteri Lingkungan Hidup Republik Indonesia Nomor P.52/MENLHK/SETJEN/KUM.1/9/2009 tentang Gerakan Peduli Dan Berbudaya Lingkungan Di Sekolah; Peraturan Menteri Lingkungan Hidup Republik Indonesia Nomor P.53/MENLHK/SETJEN/KUM.1 /9/2009 tentang Penghargaan Adiwiyata; Kesepakatan Bersama Menteri Negera Lingkungan Hidup dengan Menteri Pendidikan Nasional Nomor: O3/MENLH/02/2010dan Nomor: 01/II/KB/2010.

Meskipun telah ada kebijakan yang dikeluarkan oleh Kementrian Lingkungan Hidup Dan Kehutanan, tetapi seyogyanya juga perlu adanya kebijakan yang dikembangkan secara mandiri oleh sekolah-sekolah. Kebijakan tersebut berupa visi dan misi sekolah yang peduli dan berbudaya lingkungan, yang dituangkan dalam tata tertib sekolah; kebijakan sekolah dalam mengembangkan pola pembelajaran pendidikan lingkungan hidup, yang dilakukan dengan sosialisasi dan komunikasi dari tenaga pengajar ke peserta didik; kebijakan peningkatan kapasitas sumber daya manusia (kependidikan dan non-kependidikan) di bidang lingkungan hidup, dimana para tenaga pengajar mengikuti pelatihan dan seminar tentang pelaksanaan program adiwiyata; kebijakan sekolah dalam penghematan sumber daya alam, dilakukan dengan adanya gerakan sekolah melakukan penghematan penggunaan air, listrik, dan kertas; kebijakan sekolah untuk menciptakan lingkungan hidup yang baik dan sehat, dengan mewujudkan lingkungan sekolah yang asri dan bersih sehingga menciptakan situasi yang kondusif untuk kegiatan belajar mengajar. Di samping itu juga perlu adanya kebijakan terkait sumber dana dan alokasinya untuk kegiatan pendidikan lingkungan hidup dalam program adiwiyata di sekolah tersebut, dalam hal ini sangat diperlukan adanya kerjasama dan partisipasi dari dinas terkait terhadap sekolah tersebut untuk mensukseskan program adiwiyata tersebut.

Kolaborasi kebijakan yang dikeluarkan Pemerintah dengan kebijakan mandiri dari sekolah tersebut perlu digalakkan di seluruh Indonesia. Hal tersebut bertujuan untuk mencetak generasi penerus bangsa yang peduli lingkungan. Terkait dengan pelaksanaan program adiwiyata di sekolah baik di tingkat SD, SMP, SMA tersebut masih banyak sekolah-sekolah memiliki anggapan keliru mengenai Gerakan PBLHS ini. Sekolah-sekolah tersebut masih beranggapan bahwa untuk melaksanakan Gerakan PBLHS ini membutuhkan modal yang besar (mahal) karena sekolah harus menyediakan sarana dan prasarana yang menunjang untuk kegiatan tersebut. Padahal kegiatan adiwiyata ini ditekankan untuk ke "gerakannya", lebih fokus kepada perilaku warga sekolah untuk peduli dan berbudaya lingkungan hidup. Kegiatan yang dapat dilakukan melalui pengintegrasian materi lingkungan hidup (perilaku ramah lingkungan hidup/PRLH) ke dalam kurikulum pendidikan yang dituangkan dalam mata pelajaran, ekstra kurikuler, serta perilaku ramah dan peduli lingkungan hidup. 
Dalam hal ini, di sisi lain ketika sekolah berusaha untuk mengintegrasikan perilaku ramah lingkungan hidup dalam kurikulum pendidikan, masih banyak para tenaga pengajar yang belum memiliki pengetahuan yang mumpuni tentang pelestarian fungsi lingkungan hidup tersebut. Masih banyak tenaga pengajar yang belum dapat mengimplementasikan pelestarian fungsi lingkungan hidup serta kegiatan perilaku ramah lingkungan hidup tersebut ke dalam kurikulum pendidikan. Di samping itu, banyak tenaga pengajar tersebut belum paham cara mengaplikasikan dan mengajarkan kurikulum pendidikan lingkungan hidup tersebut kepada para peserta didik.

Terkait hal tersebut di atas, perlu dilakukan pembinaan, pendampingan, serta sosialisasi secara intensif ke sekolah-sekolah agar para tenaga pendidik tersebut memiliki pemahaman yang optimal terhadap kegatan-kegiatan pelestarian fungsi lingkungan hidup. Di samping itu juga perlu adanya pembinaan dan pelatihan bagi tenaga pengajar dalam mengimplementasikan kegiatan pelestarian fungsi lingkungan hidup tersebut ke dalam kurikulum pendidikan lingkungan hidup. Program tersebut dapat dilakukan berdasarkan kerjasama antar instansi Dinas Lingkungan Hidup dan Dinas Pendidikan, para tenaga pengajar, serta mitra pendukung atau organisasi lingkungan hidup yang peduli terhadap kegiatan adiwiyata ini.

\subsection{Kebijakan Program Adiwiyata Efektif Dalam Mencetak Generasi Penerus Bangsa}

Para peserta didik (murid) perlu diberikan pemahaman sedari dini terkait bagaimana menjaga dan melestarikan lingkungan di sekitarnya. Sekolah sebagai tempat dimana para murid menimba ilmu, menjadi tempat yang tepat bagi para murid untuk belajar menghargai dan merawat alam, selain tentunya pendidikan lingkungan dari keluarga. Pendidikan Lingkungan Hidup dilakukan sebagai upaya untuk meningkatkan pemahaman dan kepedulian masyarakat dalam mencari solusi dan mencegah timbulnya masalah lingkungan di masa yang akan dating (Tompodung et al., 2018). Perilaku peduli lingkungan hidup masih sangat minim, termasuk di kalangan peserta didik. Program Adiwiyata merupakan program pemerintah yang diciptakan akibat penurunan kualitas lingkungan melalui pendidikan. Kualitas lingkungan yang menurun berkaitan dengan ketidakpedulian masyarakat terhadap lingkungan (Rakhmawati, 2015). Upaya untuk membentuk perilaku peduli lingkungan di kalangan peserta didik melalui penerapan program Adiwiyata di pendidikan formal pada semua jenjang sekolah (Iswari \& Utomo, 2017: 35-41).

Berdasar Pasal 2 Peraturan Menteri Negara Lingkungan Hidup Nomor 5 Tahun 2013, program adiwiyata dilaksanakan berdasarkan prinsip edukatif, partisipatif, dan berkelanjutan. Pengertian partisipatif ini merupakan komunitas sekolah terlibat dalam manajemen sekolah yang meliputi keseluruhan proses perencanaan, pelaksanaan dan evaluasi sesuai tanggungjawab dan peran. Adapun pengertian berkelanjutan merupakan seluruh kegiatan harus dilakukan secara terencana dan terus menerus secara komprehensif (Laila, 2018). 
Prinsip partisipatif di sini melibatkan seluruh elemen warga sekolah untuk mendukung program adiwiyata. Prisip berkelanjutan di sini mendorong para peserta didik untuk bersama dengan pengajar bersama masyarakat sekitar sekolah melakukan kegiatan pelestarian fungsi lingkungan. Adapun terkait prinsip edukatif di sini, dengan dimasukkannya program adiwiyata dalam kurikulum pendidikan sekolah, akan mendorong siswa untuk peduli terhadap lingkungan hidup di sekitarnya. Dalam hal ini akan membawa suasana asri dan kondusif di sekolah, sehingga memberikan semangat dalam proses belajar mengajar semakin giat. Ketiga prinsip tersebut bertujuan untuk dapat memberikan motivasi kepada para peserta didik dalam menjaga kelestarian lingkungan hidup, terekam dengan baik di dalam benak dan mental mereka. Para murid tersebut nantinya akan menjadi generasi muda penerus bangsa yang secara berkelanjutan peduli terhadap lingkungan hidup.

Berdasar Pasal 6 Peraturan Menteri Negara Lingkungan Hidup Nomor 5 Tahun 2013, menyatakan tentang komponen pelaksanaan program adiwiyata yang meliputi: aspek kebijakan sekolah yang berwawasan lingkungan; aspek kurikulum sekolah berbasis lingkungan, aspek kegiatan sekolah berbasis partisipatif; aspek pengelolaan sarana dan prasarana pendukung sekolah yang ramah lingkungan.

Aspek kebijakan sekolah berwawasan lingkungan meliputi: (1) rencana kegiatan dan anggaran sekolah memuat upaya perlindungan dan pengelolaan lingkungan hidup, meliputi kesiswaan, kurikulum dan kegiatan pembelajaran, peningkatan kapasitas pendidik dan tenaga kependidikan, sarana dan prasarana, budaya dan lingkungan sekolah, peran masyarakat dan kemitraan, peningkatan dan pengembangan mutu; (2) struktur kurikulum memuat materi terkait kebijakan perlindungan dan pengelolaan lingkungan hidup; dan (3) visi, misi, dan tujuan lembaga pendidikan memuat kebijakan perlindungan dan pengelolaan lingkungan hidup (Desfandi et al., 2017).

Program adiwiyata ini dapat berjalan dengan adanya kerjasama dari pemerintah dan warga sekitar sekolah. Penyediaan sarana dan prasarana utuk mendukung kegiatan tersebut dilakukan dengan penyediaan bibit tanaman, penyediaan tempat sampah terpisah, komposter, maupun sosialisasi dari dinas terkait mengenai pendidikan lingkungan hidup. Di samping itu, keterlibatan orangtua dalam pendidikan lingkungan hidup mempunyai peranan penting kepada anaknya yang secara langsung diterapkan dalam keluarga. Hal tersebut sangat berpengaruh terhadap kepedulian anak/siswa dalam partisipasinya untuk menjaga dan melestarikan lingkungan hidup. Contoh yang dapat diterapkan adalah dengan mengajarkan anak membuang sampah pada tempatnya (Desfandi et al., 2017).

Pendidikan di Indonedia digambarkan memberikan dampak yang konstruktif dan melahirkan sumber daya manusia yang berkualitas (Sudarwati, 2012). Pelaksanaan pendidikan dilakukan dengan pembuatan kurikulum untuk melakukan kegiatan belajar mengajar di sekolah. Tidak terkecuali pembuatan kurikulum berasis lingkungan hidup atau kurikulum berwawasan lingkungan hidup. Pelaksanaan kurikulum berbasis lingkungan merupakan kebijakan dari Dinas Pendidikan, untuk integrasi dalam mata pelajaran merupakan kebijakan dari sekolah. Pelaksanaan 
kurikulum berbasis lingkungan pada dasarnya merupakan salah satu komponen dalam pelaksanaan program adiwiyata di sekolah. Salah satu aspek terpenting dan yang sangat berpengaruh dalam keberhasilan suatu pendidikan yaitu kurikulum karena pada dasarnya kurikulum memiliki peran strategis dalam sistem pendidikan salah satunya dalam mewujudkan sekolah yang bermutu dan berkualitas. Kurikulum merupakan suatu sistem program pembelajaran untuk mencapai tujuan institusional pada lembaga pendidikan sehingga ikulum memberikan pengaruh yang besar dalam mewujudkan sekolah yang berkualitas. Guru sebagai tenaga pendidik juga memiliki peranan yang penting dalam implementasi kurikulum karena guru merupakan pelaksana pengajaran kepada peserta didik, seluruh keberhasilan suatu pembelajaran berada di tangan seorang guru sehingga guru memiliki peranan penting dalam keberhasilan pelaksanaan kurikulum (Nurhayati \& Savira, 2015) Program adiwiyata merupakan program dari Kementerian Negara Lingkungan Hidup dalam rangka penerapan Kesepakatan Bersama antara Menteri Negara Lingkungan Hidup dengan Menteri Pendidikan Nasional Nomor: O3/MENLH/02/2010 dan Nomor: 01/II/KB/2010. Berdasarkan Pasal 36 ayat (1) menyatakan bahwa "pengembangan kurikulum dilakukan dengan mengacu pada standar nasional pendidikan untuk mewujudkan tujuan pendidikan nasional". Di samping itu kurikulum tersebut juga dinyatakan dalam Pasal 36 ayat (2) yaitu "kurikulum pada semua jenjang dan jenis pendidikan dikembangkan dengan prinsip diversifikasi sesuai dengan satuan pendidikan, potensi daerah, dan peserta didik". Berdasar pernyataan pasal tersebut di atas, kurikulum berbasis lingkungan tetap mengacu pada kurikulum pada umumnya dengan mengacu pada standar nasional pendidikan dan untuk pengembangan kurikulum lebih lanjut dikembangkan sendiri oleh sekolah yang bersangkutan. Terkait kurikulum berbasis lingkungan tersebut diperlukan tenaga pendidik yang terampil dalam mengembangkan pembelajaran untuk mengimplementasikan kurikulum berbasis lingkungan.

Aspek kegiatan sekolah berbasis partisipatif ini dilakukan dengan menjalin kemitraan dalam rangka perlindungan dan pengelolaan lingkungan hidup dengan berbagai pihak (masyarakat, pemerintah, swasta, media, sekolah lain) (Algamar, n.d.). Hal tersebut dilakukan dengan bermacam kegiatan meliputi: 1) memanfaatkan narasumber untuk meningkatkan pembelajaran lingkungan hidup; 2) mendapatkan dukungan dari kalangan yang terkait dengan sekolah;3) menjadi narasumber dalam rangka pembelajaran lingkungan hidup; 4) meningkatkan peran komite sekolah dalam membangun kemitraan untuk pembelajaran lingkungan hidup serta perlindungan dan pengelolaan lingkungan hidup; 5) memberi dukungan untuk meningkatkan upaya perlindungan dan pengelolaan lingkungan hidup (Algamar, n.d.). Aspek kegiatan sekolah berbasis partisipatif ini perlu dilakukan untuk kelancaran program adiwiyata bagi sekolah yang mengikutinya.

Aspek pengelolaan sarana dan prasarana pendukung sekolah yang ramah lingkungan dilakukan melalui pemeliharaan dan pemanfaatan sarana dan prasarana yang ramah lingkungan. Kegiatan yang dapat dilakukan pada beberapa sekolah pengikut program adiwiyata meliputi antara lain pemakaian listrik dan air secara hemat, penggunaan kertas secara hemat dan pemanfaatan kertas daur ulang; 
meningkatkan kualitas pelayanan kantin di sekolah; mengurangi penggunaan plastic dalam aktifitas siswa, serta pemilahan sampah.

Terkait prinsip kelanjutan, sangat efektif program adiwiyata ini dapat mencetak generasi bangsa peduli lingkungan. Pendidikan lingkungan hidup dapat dilakukan semenjak usia dini serta diberikan pada lingkup keluarga. Contoh pendidikan ingkungan yang dapat diterapkan dari keluarga misalnya mendidik anak membuang sampah pada tempatnya, memilah sampah, menghemat pemakaian air dan listrik, serta mengambil makanan untuk dimakan secukupnya. Jika pendidikan lingkungan tersebut telah melekat dan tertanam dalam benak dan hati anak sedari dini, maka diharapkan anak dan generasi muda tersebut akan peduli terhadap lingkungan.

Dalam hal ini, terkait prinsip edukasi, dapat disampaikan bahwa program adiwiyata harus dilaksanakan dengan penuh kesungguhan antar semua komponen yang ada di sekolah tersebut. Peran aktif para warga sekolah dalam membentuk karakter untuk melakukan pendidikan lingkungan hidup sangat dibutuhkan. Keterlibatan siswa secara aktif dalam kegiatan perlindungan dan pengelolaan lingkungan hidup di sekolah, tidak hanya memberi pengetahuan dan pendidikan mengenai lingkungan hidup saja, tetapi untuk menumbuhkan dan menanamkan sikap serta karakter yang ramah lingkungan. Kebijakan kurikulum berwawasan lingkungan di sekolah belum sepenuhnya efektif dilaksanakan karena kurangnya komunikasi dan sosialisasi dari pihak sekolah kepada para murid. Hal tersebut juga dapat berjalan dengan lancar jika dilakukan sosialisasi kepada para orang tua/wali murid terkait dengan berbagai kegiatan yang dilakukan untuk program adiwiyata.

Di samping itu terkait aspek partisipatif, dapat dikatakan bahwa keterlibatan warga serta dinas yang terkait dalam mengakomodasi sarana dan prasarana yang diperlukan tersebut masih kurang. Hal ini disebabkan kurangnya sosialisasi terkait program adiwiyata tersebut dari dinas terkait kepada masyarakat. Oleh karena itu, koordinasi dengan pihak sekolah (kepala sekolah, tenaga pengajar, peserta didik, orang tua/wali murid), warga di sekitar sekolah serta dinas yang terkait sangat berperan penting dalam keberhasilan pelaksanaan program adiwiyata tersebut.

\subsection{Perlunya Peran Pemerintah Terkait Efektifitas Kebijakan Program Adiwiyata Dalam Mencetak Generasi Penerus Bangsa Yang Peduli Lingkungan Di Indonesia}

Terkait dengan pelaksanaan program adiwiyata yang dilakukan oleh sekolah SD dan/atau sederajat; SMP dan.atau sederajat; SMA dan/atau sederajat, Pemerintah memberikan hadiah/reward bagi sekolah yang berhasil dan mendapatkan point tertinggi dalam melakukan kegiatan pelestarian fungsi lingkungan hidup di sekolahnya. Tujuan pemberian penghargaan adiwiyata tersebut untuk mewujudkan perilaku ramah lingkungan hidup dari warga sekolah. Penghargaan adiwiyata diatur dalam Peraturan Menteri Lingkungan Hidup Nomor P.53/MENLHK/SETJEN/KUM.1/9/2009. Pasal 1 butir 1 peraturan memberikan definisi mengenai penghargaan adiwiyata, dinyatakan dengan "adiwiyata adalah penghargaan yang diberikan oleh pemerintah, pemerintah daerah provinsi, dan 
pemerintah daerah kabupaten/kota kepada sekolah yang berhasil melaksanakan gerakan peduli dan berbudaya lingkungan hidup di sekolah.

Pasal 1 butir 1 Peraturan Menteri Lingkungan Hidup Republik Indonesia Nomor P.52/MENLHK/SETJEN/KUM.1/9/2009 tentang Gerakan Peduli Dan Berbudaya Lingkungan Di Sekolah; yang dimaksud dengan pendidikan lingkungan hidup adalah upaya untuk meningkatkan pengetahuan, keterampilan, sikap, dan aksi kepedulian individu, komunitas, organisasi dan berbagai pihak terhadap permasalahan lingkungan untuk keberlanjutan pembangunan bagi generasi sekarang dan yang akan datang. Pasal 2 butir 1 Peraturan Menteri Lingkungan Hidup Republik Indonesia Nomor P.52/MENLHK/SETJEN/KUM.1/9/2009 tentang Gerakan Peduli Dan Berbudaya Lingkungan Di Sekolah; adapun pengertian dari gerakan peduli dan berbudaya lingkungan di sekolah (Gerakan PBLS) adalah aksi kolektif secara sadar, sukarela, berjejaring, dan berkelanjutan yang dilakukan oleh Sekolah dalam menerapkan perilaku ramah lingkungan hidup.

Pasal 2 ayat (1) Peraturan Menteri Lingkungan Hidup Republik Indonesia Nomor P.53/MENLHK/SETJEN/KUM.1/9/2009 tentang Penghargaan Adiwiyata; penghargaan Adiwiyata diberikan oleh Menteri, gubernur, dan bupati/wali kota kepada sekolah yang berhasil melaksanakan gerakan peduli dan berbudaya lingkungan hidup di sekolah. Pasal 3 Peraturan Menteri Lingkungan Hidup Republik Indonesia Nomor P.53/MENLHK/SETJEN/KUM.1/9/2009 tentang Penghargaan Adiwiyata; pemberian penghargaan adiwiyata dilakukan berdasarkan penilaian terhadap calon sekolah adiwiyata meliputi tingkat kabupaten kota, tingkat propinsi, tingkat nasional, serta tingkat mandiri. Pasal 4 Peraturan Menteri Lingkungan Hidup Republik Indonesia Nomor P.53/MENLHK/SETJEN/KUM.1/9/2009 tentang Penghargaan Adiwiyata; penilaian calon sekolah adiwiyata dilakukan melalui seleksi administrasi serta pemenuhan kriteria sekolah adiwiyata.

Penilaian Sekolah Adiwiyata tersebut berdasarkan pemenuhan kriteria sekolah adiwiyata yang terdiri dari 3 (tiga) komponen. 3 (tiga) komponen tersebut meliputi perencanaan gerakan PBLHS; pelaksanaan gerakan PBLHS; serta pemantauan dan evaluasi gerakan PBLHS. Penetapan sebagai Sekolah Adiwiyata tersebut berdasar 4 (empat) penilaian yang telah ditentukan. Pertama, sekolah yang mencapai nilai paling sedikit $70 \%$ (tujuh puluh perseratus) dari nilai capaian tertinggi ditetapkan sebagai Sekolah Adiwiyata kabupaten/kota. Kedua, sekolah yang mencapai nilai paling sedikit $80 \%$ (delapan puluh perseratus) dari nilai capaian tertinggi dan telah mendapatkan penghargaan Adiwiyata kabupaten/kota paling singkat 12 (duabelas) bulan sebelumnya, ditetapkan sebagai Sekolah Adiwiyata provinsi. Ketiga, sekolah yang mencapai nilai paling sedikit $90 \%$ (sembilan puluh perseratus) dari nilai capaian tertinggi, dan telah mendapatkan penghargaan Adiwiyata provinsi paling singkat 12 (dua belas)bulan sebelumnya, ditetapkan sebagai Sekolah Adiwiyata nasional. Keempat, sekolah yang mencapai nilai paling sedikit 95\% (sembilan puluh lima perseratus) dari nilai capaian tertinggi, dan telah mendapatkan penghargaan Adiwiyata nasional paling singkat 12 (dua belas) bulan sebelumnya serta telah 
berhasil membina paling sedikit 2 (dua) sekolah, ditetapkan sebagai Sekolah Adiwiyata mandiri.

Dijelaskan dalam Pasal 6 Peraturan Menteri Negara Lingkungan Hidup Nomor 2 Tahun 2009 tentang Pedoman Pelaksanaan Program Adiwiyata, dijelaskan mengenai kriteria penilaian program adiwiyata di sekolah-sekolah. Kriteria tersebut meliputi: memiliki kebijakan sekolah yang berwawasan lingkungan; memiliki dan melaksanakan kurikulum sekolah berwawasan lingkungan; melaksanakan kegiatan sekolah berbasis partisipatif; serta memiliki sarana dan prasarana pendukung sekolah yang ramah lingkungan.

Pada tahun 2019 ini, Kementrian Lingkungan Hidup Dan Kehutanan Republik Indonesia menetapkan sebanyak 434 sekolah yang terdiri dari 376 sekolah negeri dan 58 sekolah swasta dari 164 kota/kabupaten berhasil mendapatkan penghargaan adiwiyata nasional dan penghargaan adiwiyata mandiri. Sebanyak 333 sekolah mendapatkan penghargaan adiwiyata nasional serta 101 sekolah mendapatkan penghargaan adiwiyata mandiri yang berasal dari 32 propinsi dari seluruh Indonesia (Violleta, 2019). Adapun pada tahun 2019 di Kota Yogyakarta, SD Serayu mendapatkan penghargaan adiwiyata mandiri. Penghargaan adiwiyata mandiri tersebut merupakan pencapaian tertinggi yang dapat diraih oleh sebuah sekolah dalam proses menjadi sekolah adiwiyata berwawasan dan berbudaya lingkungan (Mutiara, 2019).

Adapun pada tahun 2018, sebanyak 279 sekolah mendapat penghargaan adiwiyata nasional serta 117 sekolah mendapat penghargaan adiwiyata mandiri (Herlinawati, 2018). Pada tahun 2018, penghargaan adiwiyata tingkat propinsi untuk Propinsi Daerah Istimewa Yogyakarta diberikan kepada 6 sekolah SD/MI; 5 sekolah SMP/MTs; dan 5 sekolah SMA/SMK/MA.

Dalam rangka menumbuhkembangkan pengetahuan, wawasan, nilai, kepedulian, sikap dan perilaku yang ramah terhadap lingkungan hidup bagi warga sekolah (peserta didik dan tenaga pengajar) serta menguatkan kapasitas kelembagaan pemerintahan daerah dalam rangka mendukung pendidikan lingkungan hidup yang sesuai dengan pembangunan berkelanjutan, maka telah diatur suatu ketentuan bersama dari berbagai instansi yang terlibat dalam pelaksanaan program adiwiyata tersebut. Terkait hal tersebut, Kementerian Kehutanan dan Lingkungan Hidup, Kementerian Pendidikan dan Kebudayaan, Kementerian Riset Teknologi dan Pendidikan Tinggi, Kementerian Agama, dan Kementerian Dalam Negeri telah menandatangani Nota Kesepahaman. Nota kesepahamana yang dimaksud tersebut adalah Nota Kesepahaman Nomor: PKS.2/MENLHK/ P2SDM/KUM.3/7/2016, Nomor: 99/VII/NK/2016, Nomor: 11a/M/NK/2016, Nomor: 9 Tahun 2016, dan Nomor: 660/2688A/SJ tentang Pengembangan Pendidikan Lingkungan Hidup pada tanggal 22 Juli 2016.

Sebagai bentuk pelaksanaan dari Nota Kesepahaman dimaksud, dan untuk mewujudkan satuan pendidikan yang peduli dan berbudaya lingkungan hidup serta menguatkan kapasitas kelembagaan pemerintahan daerah dalam rangka mendukung perwujudan satuan pendidikan yang peduli dan berbudaya lingkungan 
hidup, Kepala Badan P2SDM Kementerian Lingkungan Hidup dan Kehutanan, dan Sekretaris Jenderal Kementerian Pendidikan dan Kebudayaan, dan Direktur Jenderal Pembelajaran dan Kemahasiswaan Kementerian Riset, Teknologi dan Pendidikan Tinggi, dan Sekretaris Jenderal Kementerian Agama, dan Direktur Jenderal Bina Pembangunan Daerah Kementerian Dalam Negeri telah menandatangani Perjanjian Kerja Sama Nomor: PKS.1/P2SDM/ LATMAS/SDM.2/12/2017, Nomor: 13/XII/PKS/2017, Nomor: 001/B/PKS/2017, Nomor: 4 TAHUN 2017, Nomor: 193/9828/Bangda, tentang Gerakan Peduli dan Berbudaya Lingkungan Hidup Pada Satuan Pendidikan pada tanggal 21 Desember 2017.

Program adiwiyata tersebut perlu untuk dikembangkan agar mampu mewujudkan dan menghadirkan warga sekolah yang bertanggung jawab dalam perlindungan dan pengelolaan lingkungan hidup. Program adiwiyata mencakup penilaian kebijakan sekolah, kurikulum, kegiatan lingkungan berbasis partisipatif dan pengelolaan sarana pendukung ramah lingkungan di sekolah. Pemberian penghargaan adiwiyata nasional dan mandiri dilakukan sejak tahun 2006.

Fungsi sekolah adiwiyata atau Gerakan Peduli Dan Berbudaya Lingkungan Hidup Di Sekolah (PBLHS) agar seluruh peserta didik ikut terlibat dalam segala kegiatan atau aktifitas persekolahan demi menuju lingkungan yang sehat dan juga mampu menghindari dampak lingkungan yang negative sekaligus sebagai salah satu upaya dalam mendukung ketahanan bencana warga sekolah. Terkait hal tersebut Pemerintah berupaya menyadarkan manusia agar berperilaku ramah lingkungan melalui kegiatan pendidikan lingkungan hidup. Kegiatan tersebut menekankan pada pengetahuan, tindakan serta kesadaran masyarakat tentang pendidikan pembangunan berkelanjutan. Pembangunan berkelanjutan di sini bukan hanya sekedar menghormati lingkungan, tetapi juga memikirkan bagaimana keberlanjutan kehidupan manusi, yang produktif dan sehat dalam hubungan harmonis dengan alam (Susilo, 2014: 187). Bentuk pembelajaran pendidikan lingkungan hidup tidak hanya berupa materi, tetapi juga diperlukan pembelajaran langsung yang berhubungan dengan alam secara nyata, sehingga pembelajaran yang diberikan pada siswa lebih mudah dipahami serta sesuai sasaran (Uyun et al., 2020: 12-13).

Terkait pemaparan yang disampaikan di atas, tidak hanya melakukan penilaian sekolah adiwiyata serta pemberian penghargaan adiwiyata saja yang merupakan peran dari Pemerintah dalam pelaksanaan program ini. Di samping itu peran yang dilakukan Pemerintah berupa: sosialisasi yang diberikan Pemerintah (dinas terkait) kepada sekolah-sekolah yang mengikuti program adiwiyata; pemberian dana untuk pelaksanaan program adiwiyata di sekolah dalam melakukan pendidikan lingkungan hidup; menyiapkan dan memberikan sarana dan prasarana untuk mendukung program adiwiyata, seperti pemberian bibit tanaman, pemberian tong sampah untuk kegiatan pemilahan sampah; pemberian informasi tentang penyaluran hasil kreasi daur ulang sampah; mengadakan berbagai pelatihan yang ditujukan kepada para tenaga pengajar dalam mengkreasikan program adiwiyata yang diterapkan di sekolah-sekolah; mengajak warga masyarakat untuk berpartisipasi dan mendukung program adiwiyata, serta bekerjasama dengan 
kementrian atau dinas lain untuk membuat kurikulum berwawasan lingkungan hidup.

\section{Kesimpulan}

Berdasarkan hasil penelitian dan pembahasan yang telah disampaikan di atas dapat disimpulkan bahwa: Kebijakan program adiwiyata dalam mencetak generasi penerus bangsa yang peduli lingkungan perlu digalakkan di sekolah seluruh Indonesia dari tingkat dasar sampai menengah, karena bernilai positif bagi perkembangan generasi penerus bangsa dalam upaya melestarikan fungsi lingkungan hidup. Program ini diharapkan dapat mewujudkan lingkungan hidup yang baik dan sehat, dimana akan memacu dan menambah semangat serta optimis kegiatan belajar mengajar, dalam hal pendidikan lingkungan hidup. Kebijakan program adiwiyata telah berjalan efektif dalam mencetak generasi penerus bangsa, meski belum berjalan secara optimal. Aspek edukasi, aspek partisipatif, dan aspek berkelanjutan belum secara optimal dilakukan oleh para tenaga pengajar dalam melakukan pendidikan lingkungan hidup kepada para peserta didiknya. Peran Pemerintah diperlukan terkait kebijakan program adiwiyata dalam mencetak generasi penerus bangsa yang peduli lingkungan di Indonesia. Hal tersebut penting karena Pemerintah berupaya memberikan kesadaran lingkungan kepada masyarakat, salah satu wujud pelaksanaannya dilakukan dengan melakukan program adiwiyata di sekolah. Sosialisasi serta kesiapan sarana dan prasarana dalam mendukung program adiwiyata merupakan peran Pemerintah dalam berupaya mencetak generasi penerus bangsa peduli lingkungan hidup.

\section{Daftar Referensi}

Algamar. (n.d.). Metode Evaluasi 2 Standar (Kegiatan Lingungan Berbasis Partisipatif Dan Pengelolaan Sarana Pendukung Ramah Lingkungan).

Desfandi, M., Maryani, E., \& Disman. (2017). Implementasi Kebijakan Sekolah Berwawasan Lingkungan Sebagai Upaya Mengembangkan Literasi Ekologis Peserta Didik. SOSIO-DIDAKTIKA: Social Science Education Journal, 4(2), 30-38.

Fadli, M., Mukhlis, \& Lutfi, M. (2016). Hukum Dan Kebijakan Lingkungan. UB Press.

Hadi, D. W. (2019). 434 Sekolah Raih Penghargaan Adiwiyata Tahun 2019. Biro Hubungan Masyarakat KLHK. https:// ppid.menlhk.go.id/siaran_pers/browse/2254

Haris, E., Abas, H. M., \& Wardiana, Y. (2018). Sekolah Adiwiyata, Panduan Implementasi Adiwiyata Mandiri Di Sekolah. Erlangga.

Herlinawati, M. (2018). 396 Sekolah Terima Penghargaan Lingkungan Adiwiyata. Antaranews.Com. https:/ / www.antaranews.com/berita/780160/396-sekolahterima-penghargaan-lingkungan-adiwiyata

Ibeng, P. (2019). Pengertian Adiwiyata, Tujuan, Fungsi, Kriteria, Dan Manfaatnya. Pendidikan.Co.Id. https:// pendidikan.co.id/pengertian-adiwiyata/ 
Iswari, R. D., \& Utomo, S. W. (2017). Evaluasi Penerapan Program Adiwiyata Untuk Membentuk Perilaku Peduli Lingkungan Di Kalangan Siswa (Kasus: SMA Negeri 9 Tangerang Selatan Dan MA Negeri 1 Serpong). Jurnal Ilmu Lingkungan, 15(1), 35-41.

Laila, K. E. (2018). Sekolah Adiwiyata - Partisipatif Dan Berkelanjutan. Provisieducation.Com. ttps://www.provisieducation.com/from-thefield/sekolah-adiwiyata-partisipatif-dan-berkelanjutan

Muladi. (2009). Hak Asasi Manusia, Hakekat, Konsep, Dan Implikasinya Dalam Perspektif Hukum Dan Masyarakat. Refika Aditama.

Mutiara, N. (2019). SDN Serayu Berhasil Meraih Penghargaan Adiwiyata Mandiri. Lingkunganhidup.Jogjakota.Go.Id. https:// lingkunganhidup.jogjakota.go.id/detail/index/257

Nurhayati, E., \& Savira, S. I. (2015). Implementasi Kurikulum Berbasis Lingkungan di Sekolah Adiwiyata (Studi Kasus di SMP Negeri 16Surabaya). Inspirasi Manajemen Pendidikan, 2(2).

Rahmadi, T. (2019). Hukum Lingkungan di Indonesia. Rajawali Pers.

Rakhmawati, D. (2015). Model Pengembangan Karakter Peduli Lingkungan Siswa Sekolah Adiwiyata Mandiri: Studi Ksus Di Sekolah Menengah Kejuruan 2 Semarang. Universitas Negeri Semarang.

Silalahi, M. D., \& Kristianto. (2015). Hukum Lingkungan Dalam Perkembangannya Di Indonesia. Keni Media.

Sod, M. (2019). Hukum Lingkungan Di Indonesia. Sinar Grafika.

Sudarwati, T. M. (2012). Implementasi Kebijakan Pendidikan Lingkungan Hidup Sekolah Menegah Atas Negeri 11 Semarang Menuju Sekolah Adiwiyata. Universitas Diponegoro.

Susilo, R. K. D. (2014). Sosiologi Lingkungan. Raja Grafindo Persada.

Tim Kajian Kerjasama ICEL dan IICT. (2005). Hak Atas Lingkungan Hidup (Sebuah Kajian Prinsip-Prinsip HAM Dalam Instrumen Nasional). Komisi Nasional Hak Asasi Manusia.

Tompodung, T. C. G., Rushayati, S. B., \& Aidi, M. N. (2018). Efektifitas Program Adiwiyata Terhadap Perilaku Ramah Lingkungan Warga Sekolah Di Kota Depok. Jurnal Pengelolaan Sumberdaya Alam Dan Lingkungan (Journal of Natural Resources and Environmental Management), 8(2), 170-177. https:// doi.org/10.29244/jpsl.8.2.170-177

Uyun, S., Octavia, S. A., Muharom, A., \& Hilaliah, L. (2020). Manajemen Sekolah/Madrasah Adiwiyata. Deepublish.

Violleta, P. T. (2019). KLHK Beri Penghargaan Adiwiyata Untuk Sekolah Peduli Lingkungan.

Antaranews.Com.

https://www.antaranews.com/berita/1207852/klhk-beri-penghargaan- 
adiwiyata-untuk-sekolah-peduli-lingkungan

Widyaningrum, L. (2019). Meningkatkan Budaya Sekolah Berwawasan Lingkungan Guna Menciptakan Sekolah Adiwiyata. Researchgate.Net. https://www.researchgate.net/publication/338237523_Meningkatkan_Buday a_Sekolah_Berwawasan_Lingkungan_Guna_Menciptakan_Sekolah_Adiwiyat a 